\title{
Effect of bromochloromethane on methane emission, rumen fermentation pattern, milk yield, and fatty acid profile in lactating dairy goats
}

\author{
L. Abecia, ${ }^{\star}$ P. G. Toral, ${ }^{\star}$ A. I. Martín-García, ${ }^{\star}$ G. Martínez, ${ }^{\star}$ N. W. Tomkins,† E. Molina-Alcaide, ${ }^{\star}$ C. J. Newbold,ł \\ and D. R. Yáñez-Ruiz*1 \\ *Estación Experimental del Zaidín (CSIC), Profesor Albareda 1, 18008, Granada, Spain \\ †CSIRO Livestock Industries, ATSIP, James Cook University, Townsville, Queensland 4812, Australia \\ fIBERS, Aberystwyth University, Aberystwyth, SY23 3DA, United Kingdom
}

\section{ABSTRACT}

Several technologies have been tested to reduce enteric methanogenesis, but very few have been successfully used in practical conditions for livestock. Furthermore, the consequences of reduced rumen methane production on animal performance and milk quality are poorly understood. The aim of this work was to investigate the effect of feeding bromochloromethane (BCM), a halogenated aliphatic hydrocarbon with potential antimethanogenic activity, to dairy goats on rumen methane production, fermentation pattern, the abundance of major microbial groups, and on animal performance and milk composition. Eighteen goats were allocated to 2 experimental groups of 9 animals each: treated $(\mathrm{BCM}+)$ or not $(\mathrm{BCM}-)$ with $0.30 \mathrm{~g}$ of $\mathrm{BCM} / 100 \mathrm{~kg}$ of body weight per day. The BCM was administered per os in 2 equal doses per day from parturition to $2 \mathrm{wk}$ postweaning (10 wk). After weaning, methane emissions were recorded over 2 consecutive days (d 57 and 58 on treatment) in polycarbonate chambers. On d 59, individual rumen fluid samples were collected for volatile fatty acid (VFA) analysis and quantification of bacterial, protozoal, and archaeal numbers by realtime PCR. On d 69 and 70, daily milk production was recorded and samples were collected for determination of fat, protein, lactose, casein, and total solids concentration by infrared spectrophotometry, and fatty acid composition by gas chromatography. Treatment with BCM reduced methane production by $33 \%$ (21.6 vs. $14.4 \mathrm{~L} / \mathrm{kg}$ of DMI) compared with nontreated animals, although it did not affect the abundance of rumen bacteria, protozoa, and total methanogenic archaea. The observed improvement in the efficiency of digestive processes was accompanied by a $36 \%$ increase in milk yield, probably due to the more propionic type of rumen fermentation and an increase in VFA produc-

Received August 12, 2011.

Accepted November 19, 2011.

${ }^{1}$ Corresponding author: david.yanez@eez.csic.es tion. The increase in milk yield was not accompanied by any changes in the concentrations or yields of fat, protein, or lactose. Despite the substantial decrease in methane production, only minor changes in milk fatty acid profile were observed, suggesting that ruminal biohydrogenation pathways were not affected. Compounds that influence terminal biochemical pathways for methane production deserve further development for future application in the dairy goat sector.

Key words: caprine, rumen, methane, fatty acid

\section{INTRODUCTION}

The emission of greenhouse gases by livestock and potential abatement technologies have been the subject of many international studies in recent years (Steinfeld et al., 2006). In ruminants, methane $\left(\mathrm{CH}_{4}\right)$ production represents a loss of between 2 and $12 \%$ of the gross energy intake (Johnson and Johnson, 1995). In particular, in high-producing lactating animals, $\mathrm{CH}_{4}$ production has been estimated to constitute a loss of $6 \%$ of gross energy intake (Tamminga et al., 2007).

A variety of nutritional management strategies to reduce methane production in ruminants has been studied. Increasing the level of grain in the diet has been shown to reduce the proportion of dietary energy converted to methane mainly due to changes in the fermented substrate from fiber to starch (Blaxter and Clapperton, 1965). The addition of lipids has also been shown to reduce methane production, by essentially decreasing ruminal organic matter fermentation (Johnson and Johnson, 1995). However, it is often necessary to use relatively high quantities of supplemental lipids $(\geq 6 \%$ $\mathrm{DM})$ and this is generally associated with decreased fiber digestibility and DMI, negating the advantages of increased energy density of the diet (Beauchemin et al., 2008; Eugène et al., 2008). Furthermore, the greatest reductions in methane production have been found for lipids rich in some medium-chain FA, such as 14:0 and 16:0 (Beauchemin et al., 2008; Eugène et al., 2008), whose transfer to milk fat could detrimentally affect its 
nutritional value (Parodi, 2009). These strategies have therefore limited application in the dairy sector. On the other hand, several compounds with the potential to modify rumen fermentation through manipulation of the microbial ecosystem have been tested in vitro, but very few have been successfully used in vivo and almost none in lactating animals (McAllister and Newbold, 2008). A major constraint of feeding additives to reduce methanogenesis is that the effects observed in vitro may not persist over time in vivo. This may be related to the degradation of the active compounds by rumen microorganisms or to the ecology of the system adapting to the treatment (Hart et al., 2008).

Regardless of the mitigation practice, the side effects that a shift in rumen fermentation to substantially reduce methane production might have on the overall FA metabolism and the effect on milk composition are variable and yet poorly understood (Tamminga et al., 2007). Previous work has attempted to relate methane production to the proportions of various specific FA in the milk, such as iso 15:0 and 15:0, based on the enrichment of rumen $\mathrm{H}$-producing bacteria in these FA (Vlaeminck and Fievez, 2005; Chilliard et al., 2009). Others have suggested potential links between methane production and changes in the biohydrogenation pathways as part of the overall $\mathrm{H}_{2}$ transferring processes in the rumen (Beauchemin et al., 2008). However, almost no data are available on the milk production and milk FA profile when a substantial reduction occurs in methane emissions.

In the present work we made use of a recently developed bromochoromethane (BCM) formulation that has been shown to reduce methane production by up to $60 \%$ in steers fed grain-based diets over a 90-d feedlot finishing period (Tomkins et al., 2009) with no signs of toxicity or residues in meat and offal. Although uncomplexed BCM has an ozone-depleting effect and therefore is banned from commercial use, the strong and persistent effect on methane reduction makes it an interesting model to investigate side effects of methane reduction in dairy goats.

The aim of this work was to investigate the effect of the addition of $\mathrm{BCM}$ in the diet of dairy goats on animal performance, rumen methane production and fermentation pattern, and on milk yield, composition, and FA profile.

\section{MATERIALS AND METHODS}

All management and experimental procedures involving animals were carried out by trained personnel in strict accordance with the Spanish guidelines for experimental animal protection at the Estación Experimental del Zaidín. Experimental protocols were approved by the Ethics Committee for Animal Research from the Animal Nutrition Unit.

\section{Animals, Diet, and Experimental Design}

Eighteen Murciano-Granadina lactating goats (43 \pm $1.7 \mathrm{~kg}$ of BW) were acquired at 3 mo of pregnancy, kept in individual pens $(1.7 \times 1.2 \mathrm{~m})$ with free access to water, and fed twice a day (0900 and $1500 \mathrm{~h}$ ) a diet that consisted of alfalfa hay supplied ad libitum and a supplement of $600 \mathrm{~g} / \mathrm{d}$ of a commercial compound feed (Table 1).

The experimental period commenced 2 mo later when the kids were born and lasted for $10 \mathrm{wk}$. The goats were randomly allocated to 1 of 2 experimental groups: $\mathrm{BCM}+$, treated with $0.30 \mathrm{~g} / 100 \mathrm{~kg}$ of $\mathrm{BW}$ of $\mathrm{BCM}$ formulation per day, and BCM-, the nontreated control group. Bromochoromethane treatment was given twice a day at feeding times (0900 and $1500 \mathrm{~h}$ ). The kids remained with their mothers in individual pens for 8 wk. After kids were weaned, methane emissions of goats in open circuit respiration chambers were recorded over 2 consecutive days (d 57 and 58 on treatment).

On d 59, samples of rumen fluid were collected from each goat before the morning feeding using a stomach tube. Aliquots were stored at $-20^{\circ} \mathrm{C}$ for VFA analysis and at $-80^{\circ} \mathrm{C}$ for quantification of the main microbial groups. Over the last 2 wk of the trial, goats were kept in the same individual pens as before methane measurements and milked once a day before the morning feeding. On d 69 and 70 of the experimental period, milk yield was recorded and samples taken for the determination of fat, protein, lactose, casein, and total solids concentrations and FA profile. Goats were weighed on d 1 and 56 of the experimental period. Milk samples from one control goat were wrongly processed prior to analysis and data from this animal were therefore removed from the data analysis.

Table 1. Chemical composition $(\mathrm{g} / \mathrm{kg}$ of $\mathrm{DM})$ of the diet ingredients

\begin{tabular}{|c|c|c|c|c|c|c|c|c|}
\hline Ingredient & $\mathrm{DM}$ & $\mathrm{OM}$ & $\mathrm{CP}$ & NDF & $\mathrm{ADF}$ & $\mathrm{ADL}$ & $\mathrm{EE}^{1}$ & $\mathrm{GE}^{1}$ \\
\hline Alfalfa & 896 & 880 & 214 & 419 & 244 & 60.9 & 13.6 & 18.2 \\
\hline Concentrate $^{2}$ & 902 & 893 & 170 & 342 & 142 & 34.3 & 33.9 & 18.2 \\
\hline
\end{tabular}




\section{Antimethanogen Formulation}

The antimethanogen compound was a halogenated aliphatic hydrocarbon, BCM, entrapped in an a-cyclodextrin matrix (May et al., 1995). The formulation was prepared as a dry white powder in 1- to $2-\mathrm{kg}$ batches and contained 10 to $12 \%$ (wt/wt) BCM. The BCM complex was then wrapped in cellulose paper, mixed with $10 \mathrm{~g}$ of ground oats, and sealed with molasses.

\section{Methane Measurement}

Methane production of each goat was measured using 4 open circuit respiration chambers constructed of metal frame and polycarbonate. Each chamber measured $1.8 \mathrm{~m}$ wide $\times 1.8 \mathrm{~m}$ deep $\times 1.5 \mathrm{~m}$ tall. Chamber air temperature varied between 10 and $20^{\circ} \mathrm{C}$. Interruptions occurred daily at $0900 \mathrm{~h}$, when the chamber floor was cleaned and the goats received the morning feed, and at $1500 \mathrm{~h}$, when animals received the afternoon feed. These interruptions had little effect on the daily emissions as they lasted for around $10 \mathrm{~min}$ for each chamber and occurred when the corresponding exhaust duct was not being sampled. Fluxes were calculated twice a day and then summed to derive the 24 -h emission value. Airflow (L/min) and concentration of methane was measured for the intake and exhaust ducts of each chamber. Air stream in each duct was subsampled, and methane concentration was measured continuously using a gas analyzer (ADC MGA3000, Spurling Works, Hoddesdon, UK). The flux of methane for each chamber was calculated for the 2-d period of measurement from the fresh-air intake and chamber exhaust concentrations and mean airflow.

\section{Chemical Analyses}

Feed samples were ground through a 1-mm sieve before analysis, and DM, OM, and ether extract contents were determined following AOAC official methods 7.008, 7.010, and 7.045 (AOAC, 2005). Gross energy was determined in an adiabatic bomb calorimeter (Gallenkamp \& Co. Ltd., London, UK) according to the methodology described by Prieto et al. (1990). The $\mathrm{NDF}, \mathrm{ADF}$, and ADL analyses were performed by the sequential procedure of Van Soest et al. (1991) using the Ankom 2000 Fiber Analyzer (Ankom Technology Corp., Macedon, NY). The NDF was assayed with sodium sulfite and without $\alpha$-amylase. Both NDF and ADF were expressed without residual ash. Total nitrogen was determined by Kjeldahl analysis (AOAC 2005; method 2.055).
The VFA were analyzed by gas chromatography as described by Isac et al. (1994). The fat, protein, lactose, casein, and total solids concentrations were determined by infrared spectrophotometry (ISO 9622; ISO, 1999), using a MilkoScan FT120 (Foss Electric, Hillerød, Denmark).

For milk FA composition analysis, lipid in $200 \mathrm{mg}$ of freeze-dried milk was extracted using diethyleter and hexane $(5: 4, \mathrm{vol} / \mathrm{vol})$ and transesterified to fatty acid methyl esters (FAME) using freshly prepared methanolic sodium methoxide (Shingfield et al., 2003). Methyl esters were separated and quantified using a gas chromatograph (model Focus GC, Thermo Scientific, Milan, Italy) equipped with a flame-ionization detector and a $100-\mathrm{m}$ fused silica capillary column $(0.25 \mathrm{~mm}$ i.d., 0.2- $\mu \mathrm{m}$ film thickness; TR-CN100, Teknokroma, Barcelona, Spain) and helium as the carrier gas. Total FAME profile in a $1-\mu \mathrm{L}$ sample volume at a split ratio of 1:50 was determined using a temperature gradient program (Shingfield et al., 2003). The separation of most 18:1 isomers was satisfactory, and no further advantage was found in conducting various runs under isothermal conditions at $170^{\circ} \mathrm{C}$. Peaks were routinely identified based on retention time comparisons with authentic FAME standards when available (47885-U, N5252, and O5632, Sigma Aldrich, Madrid, Spain; 201813-9, Larodan Fine Chemicals, Malmö, Sweden), and chromatograms reported in the literature (Shingfield et al., 2003; Kramer et al., 2008). Identification was validated based on GC-MS analysis of FAME. The mass spectrometer (ITQ 900, Thermo Scientific, Austin, TX) was operated at $225^{\circ} \mathrm{C}$ in the electron impact ionization mode and mass spectra were recorded under an ionization energy of $70 \mathrm{eV}$ using helium as the carrier gas and the same temperature gradient used for routine analysis of FAME (Shingfield et al., 2003). Although the mass spectra of FAME afford limited information concerning FA structure, comparisons with an online reference library of electron impact ionization spectra (http://lipidlibrary.aocs.org/ms/masspec.html) and chromatographic retention data allowed the identification of $>96 \%$ of FAME in all samples.

\section{Real-Time PCR Analysis}

Samples of rumen contents for DNA isolation were freeze-dried and mixed by physical disruption using a bead beater (Mini-Bead Beater 8, BioSpec Products, Bartlesville, OK). Extraction was then performed on 50-mg samples using the QIAamp DNA Stool Mini Kit (Qiagen Ltd., West Sussex, UK) with a modification: a higher temperature $\left(95^{\circ} \mathrm{C}\right)$ was used for lysis incubation. The DNA samples were used as templates to 
quantify the copy numbers of $16 S r R N A$ (for bacteria), methyl coenzyme $\mathrm{M}$ reductase $\mathrm{A}(\mathrm{mcr} A)$ gene (for methanogenic archaea), and $18 S \mathrm{rRNA}$ (for protozoa) by real-time quantitative PCR (qPCR).

The yield and purity of the extracted DNA were assessed using NanoDrop ND-1000 Spectrophotometer (NanoDrop Technologies, Wilmington, DE).

Primer sets used were as follows: forward: 5'-GTGSTGCAYGGYTGTCGTCA-3' and reverse: 5'-ACGTCRTCCMCACCTTCCTC-3' for total bacteria (Maeda et al., 2003) and forward: 5'-GCTTTCGWTGGTAGTGTATT-3' and reverse: 5'-CTTGCCCTCYAATCGTWCT-3' for protozoa (Sylvester et al., 2004). The primer sets for detection and enumeration of methanogenic archaea $(\mathrm{mcr} A)$ were forward: 5'-TTCGGTGGATCDCARAGRGC-3' and reverse: 5'-GBARGTCGWAWCCGTAGAATCC-3' (Denman et al., 2007). Three replicates of each extract were used and a negative control was loaded on each plate run to screen for possible contamination or dimer formation and to set the background fluorescence for plate normalization.

Real-time PCR analyses were performed on iQ5 multicolor Real-Time PCR Detection System (BioRad Laboratories Inc., Hercules, CA). One microliter of DNA extract was added to amplification reactions (25 $\mu \mathrm{L})$ containing $0.2 \mu \mathrm{L}$ of each primer $(10 \mu M)$ and 12.5 $\mu \mathrm{L}$ of iQ SYBR Green Supermix (BioRad Laboratories Inc.). Cycling conditions were $95^{\circ} \mathrm{C}$ for $5 \mathrm{~min} ; 40$ cycles of $95^{\circ} \mathrm{C}$ for $15 \mathrm{~s}, 60^{\circ} \mathrm{C}$ for $30 \mathrm{~s}$, and $72^{\circ} \mathrm{C}$ for $55 \mathrm{~s}$; and $72^{\circ} \mathrm{C}$ for $1 \mathrm{~min}$. The threshold cycle (amplification cycle in which product formation exceeds background fluorescence) of each sample was determined during the exponential phase of amplification.

The absolute amount for each microbial group, expressed as the number of DNA copies/g of fresh matter, was determined using standards. The $\mathrm{qPCR}$ standards consisted of the plasmid pCR 4-TOPO (Invitrogen, Carlsbad, CA) with an inserted $16 S$, mcrA, or $18 S$ gene fragment corresponding to a conserved sequence of total bacteria, methanogenic archaea, or protozoa, respectively. The number of gene copies present in the plasmid extracts was calculated using the plasmid DNA concentration and the molecular mass of the vector with the insert. The concentrated plasmid was serially diluted (10-fold) to generate a standard curve.

\section{Statistical Analyses}

All data were evaluated by a 1-way ANOVA using the MIXED procedure in SAS (version 9.2, SAS Institute Inc., Cary, NC). Differences between treatment means were evaluated using the "pdiff" option of the "LS means" statement in the MIXED procedure of SAS and declared significant at $P<0.05$. A tendency was considered when $P$-values were $<0.1$.

\section{RESULTS}

\section{Methane Production, Rumen Fermentation, and Microbial Numbers}

Methane production by goats over 2 consecutive days in the chambers indicated a significant reduction in methanogenesis (Table 2) in BCM+ animals compared with control goats. Methane emissions expressed per kilogram of BW were $32 \%$ lower $(P=0.012)$ in $\mathrm{BCM}+$ than in BCM- goats. When expressed relative to DMI, methane emission was lowered by $33 \%$ in $\mathrm{BCM}+$ goats compared with BCM- goats $(P=0.013)$. The emissions per kilogram of milk produced were lower in $\mathrm{BCM}+$ goats $(P=0.051)$.

Concentrations of total VFA in the rumen were not modified by the experimental treatment (Table 2). However, VFA profile was affected by the addition of the BCM formulation, increasing the proportion of propionate and decreasing those of branched-chain VFA (namely, isobutyrate and isovalerate). As a result, the acetate:propionate ratio was significantly lower $(P<$ 0.001) in rumen fluid from BCM+ goats.

The numbers of the main microbial groups in the rumen (bacteria, protozoa, and archaea) were not modified by the addition of BCM (Table 2).

\section{Animal Performance and Milk Composition}

Dry matter intake and mean BW were not affected by the addition of BCM (Table 3). Body weight decreased between $\mathrm{d} 1$ and 56 of the experiment to the same extent in $\mathrm{BCM}+$ and $\mathrm{BCM}-$ goats. Milk yield was higher $(1,324$ vs. $971 \mathrm{~g} / \mathrm{d} ; P=0.041)$ for goats in the $\mathrm{BCM}+$ group, although the concentrations and yields of the quantified milk components (fat, protein, lactose, casein, and total solids) were not affected by treatment (Table 3).

Bromochloromethane administration had little effect on milk FA profile (Tables 4 and 5). Other than a tendency $(P=0.078)$ for a small increase $(4 \%)$ in total SFA content and a concomitant trend $(P=0.092)$ to decreased MUFA concentration $(-12 \%)$, changes in FA composition were small. These were characterized by a numerical increase in most SFA derived from de novo mammary synthesis ( $<16$ carbons), although the results only tended to be significantly different for 8:0 and 10:0 fatty acids $(P<0.10$; Table 5$)$. Similarly, the concentration of total de novo synthesized FA showed a tendency $(P=0.075)$ to be higher in milk from goats on 
Table 2. Methane emissions, total and individual VFA, and microbial numbers in the rumen contents of goats treated $(\mathrm{BCM}+)$ or not $(\mathrm{BCM}-)$ with bromochloromethane

\begin{tabular}{lcccc}
\hline Item & BCM- & BCM + & SED $^{1}$ & $P$-value \\
\hline Methane emissions & & & & \\
$\mathrm{CH}_{4}, \mathrm{~L} / \mathrm{d}$ & 22.2 & 15.1 & 2.806 & 0.043 \\
$\mathrm{CH}_{4}, \mathrm{~L} / \mathrm{kg}$ of BW & 0.515 & 0.349 & 0.063 & 0.010 \\
$\mathrm{CH}_{4}, \mathrm{~L} / \mathrm{kg}$ of DMI & 21.6 & 14.4 & 2.523 & 0.012 \\
$\mathrm{CH}_{4}, \mathrm{~L} / \mathrm{kg}$ of milk & 24.1 & 13.7 & 4.86 & 0.051 \\
$\mathrm{CH}_{4}, \mathrm{MJ} / \mathrm{d}$ & 0.829 & 0.559 & 0.080 & 0.028 \\
Percentage of gross energy intake & 4.59 & 2.95 & 0.351 & 0.008 \\
VFA concentration, mmol/L & 58.5 & 74.4 & 8.79 & 0.216 \\
Molar proportion, mmol/100 mmol & & & & \\
Acetate & 61.4 & 60.3 & 1.19 & 0.528 \\
Propionate & 11.1 & 15.5 & 0.54 & $<0.001$ \\
Butyrate & 13.5 & 13.5 & 0.68 & 0.978 \\
Isobutyrate & 5.14 & 3.78 & 0.21 & $<0.001$ \\
Valerate & 2.49 & 2.30 & 0.22 & 0.592 \\
$\quad$ Isovalerate & 6.36 & 4.52 & 0.34 & 0.004 \\
Molar ratio & & & & \\
Acetate:propionate & 5.71 & 3.92 & 0.29 & $<0.001$ \\
(Acetate + butyrate)/propionate & 6.96 & 4.80 & 0.433 & $<0.001$ \\
Microbial numbers, log gene copies/g of fresh matter & & & & \\
Bacteria & 10.3 & 10.0 & 0.116 & 0.128 \\
Protozoa & 9.58 & 9.57 & 0.083 & 0.912 \\
Methanogens & 7.98 & 7.88 & 0.211 & 0.689 \\
\hline
\end{tabular}

${ }^{1} \mathrm{SED}=$ standard error of the difference.

the $\mathrm{BCM}+$ treatment, whereas the significant decrease in the proportion of some FA, such as trans-9 18:1, cis11 20:1, the sum of some trans-trans conjugated linoleic acid (CLA) isomers, 18:3n-6, or 20:4n-6 $(P<0.05)$, were of limited biological consequence (Table 5). These latter changes did not affect the total concentration of long-chain FA (derived from the mammary uptake of circulating plasma lipids; Table 4).

In relation to the potential products of the enzyme $\Delta^{9}$-desaturase in the mammary gland, only the con- tent of a minor MUFA, cis-9 16:1, showed a trend to be lower with the experimental treatment $(P=$ 0.062; Table 5). Total CLA concentration also tended to decrease in the milk fat of goats on $\mathrm{BCM}+(P=$ 0.086), but the major CLA isomer, cis-9,trans-11 CLA ( $>73 \%$ of total CLA content) remained unmodified. Given the chromatographic conditions reported in this study, the peak of cis-9,trans-11 CLA also included the putative contribution of other minor isomers, such as trans-7,cis-9 and trans-8,cis-10 CLA. However, based

Table 3. Dry matter intake, BW, BW changes, milk production and composition in experimental goats treated $(\mathrm{BCM}+)$ or not $(\mathrm{BCM}-)$ with bromochloromethane

\begin{tabular}{lcccc}
\hline Item & BCM- & BCM + & SED $^{1}$ & $P$-value \\
\hline BW, kg & 41.6 & 43.8 & 3.55 & 0.718 \\
BW change, ${ }^{2} \mathrm{~kg}$ & -6.1 & -6.6 & 1.32 & 0.760 \\
DMI, g/d & 992 & 1,041 & 56.7 & 0.402 \\
Yield, g/d & & & & \\
Milk & 971 & 1,324 & 157 & 0.041 \\
Fat & 53.7 & 63.6 & 6.77 & 0.166 \\
Protein & 38.2 & 46.2 & 5.99 & 0.202 \\
Casein & 32.8 & 40.2 & 5.36 & 0.194 \\
Lactose & 47.7 & 63.0 & 8.16 & 0.084 \\
Total solids & 145.9 & 181.5 & 18.74 & 0.079 \\
Gross energy, MJ/d & 3.09 & 4.48 & 0.076 & 0.001 \\
Composition, g/100 g of raw milk & & & & \\
Fat & 5.46 & 4.98 & 0.701 & 0.505 \\
Protein & 3.73 & 3.52 & 0.335 & 0.551 \\
Casein & 3.18 & 3.05 & 0.252 & 0.606 \\
Lactose & 4.63 & 4.73 & 0.131 & 0.476 \\
Total solids & 14.43 & 13.90 & 0.909 & 0.570 \\
Gross energy, MJ/kg & 3.44 & 3.38 & 0.065 & 0.551 \\
\hline 19DD standar
\end{tabular}

${ }^{1} \mathrm{SED}=$ standard error of the difference.

${ }^{2}$ Over 56 d. 
Table 4. Milk FA composition ( $\mathrm{g} / 100 \mathrm{~g}$ of total $\mathrm{FA})$ and indices of desaturase activity in goats treated $(\mathrm{BCM}+)$ or not $(\mathrm{BCM}-)$ with bromochloromethane

\begin{tabular}{|c|c|c|c|c|}
\hline Item & BCM- & $\mathrm{BCM}+$ & $\mathrm{SED}^{1}$ & $P$-value \\
\hline \multicolumn{5}{|l|}{ According to degree of saturation } \\
\hline SFA & 75.66 & 78.66 & 1.577 & 0.078 \\
\hline MUFA & 19.68 & 17.33 & 1.302 & 0.092 \\
\hline \multicolumn{5}{|l|}{ According to origin ${ }^{2}$} \\
\hline$<16$ carbon $\mathrm{FA}$ & 40.76 & 43.93 & 1.646 & 0.075 \\
\hline 16 carbon FA & 29.09 & 28.59 & 1.110 & 0.660 \\
\hline \multicolumn{5}{|l|}{ Desaturase index } \\
\hline cis-9 14:1/(14:0 + cis-9 14:1) & 0.017 & 0.013 & 0.0021 & 0.136 \\
\hline cis-9 $16: 1 /(16: 0+c i s-96: 1)$ & 0.026 & 0.020 & 0.0030 & 0.076 \\
\hline cis-9 18:1/(18:0 + cis-9 18:1) & 0.693 & 0.673 & 0.0283 & 0.483 \\
\hline cis-9,trans-11 CLA $^{3} /($ trans-11 18:1 + cis-9,trans-11 CLA $)$ & 0.404 & 0.389 & 0.0258 & 0.567 \\
\hline
\end{tabular}

${ }^{1} \mathrm{SED}=$ standard error of the difference.

${ }^{2}<16$ carbon FA represent de novo synthesized FA, $>16$ carbon FA represent preformed FA taken up from circulation, and 16 carbon FA are derived from both sources.

${ }^{3} \mathrm{CLA}=$ conjugated linoleic acid.

on available reports for dairy goats (Luna et al., 2008; Bernard et al., 2009; Rodríguez-Alcalá et al., 2009), the cis-9,trans-11 CLA would be expected to account for approximately $95 \%$ of the peak area.

\section{DISCUSSION}

Interest is increasing in the study of antimethanogen compounds to reduce greenhouse gas emissions from livestock and to improve the efficiency of energy utilization. However, new technologies, especially in the form of feed additives, will have to be cost-effective and demonstrate that no residues are found in edible meat and milk. In this study, we used BCM, a halogenated compound that reacts with reduced vitamin $\mathrm{B}_{12}$ and results in the inhibition of cobamide-dependent methyl group transfer in methanogenesis (Wood et al., 1968). This compound has been shown to reduce methane production in vitro (Goel et al., 2009) and in vivo (Tomkins et al., 2009). However, to our knowledge, no published reports are available on its effect on lactating animals and on milk quality.

\section{Methane Production and Rumen Fermentation}

The reduction in methane emission in $\mathrm{BCM}+$ goats was in agreement with findings in nonlactating cattle (Tomkins et al., 2009) and in batch and continuous culture fermenters (Goel et al., 2009) using the same compound. We observed an almost $33 \%$ reduction after $57 \mathrm{~d}$ of treatment, which is lower than the 60 and $50 \%$ reductions reported by Tomkins et al. (2009), respectively, over treatments lasting 30 and $90 \mathrm{~d}$ in steers treated with the same dose $(0.30 \mathrm{~g} / 100 \mathrm{~kg}$ of BW, twice daily).
The lack of changes in DMI and the ruminal concentration of total VFA with the BCM treatment indicate that microbial fermentation in the rumen of treated animals was not compromised, as observed with other antimethanogenic treatments in which the reduction in methane emissions is related, at least in part, to decreases in DMI (Beauchemin et al., 2008). Within the VFA, the reduction in acetate:propionate due to $\mathrm{BCM}$ treatment agrees with that previously observed in steers (Denman et al., 2007). A reduction in the acetate:propionate molar ratio in the rumen has been described as a common feature of several antimethanogenic compounds, which indicates a concurrent decrease of methane formation and redirection of hydrogen from methane to more propionic metabolic pathways (McAllister and Newbold, 2008). In propionate formation, pyruvate is reduced to propionate in 1 of 2 multi-step pathways that result in less hydrogen production than in acetate synthesis and hence decreased methane synthesis (Janssen, 2010). The literature shows that the use of halogenated compounds may result in increased $\mathrm{H}_{2}$ production in the rumen (Choi et al., 2004), which in our case did not compromise anaerobic fermentation. Nevertheless, future mitigation experiments should attempt to quantify the potential increase in $\mathrm{H}_{2}$ production within the rumen.

Halogenated analogs, such as BCM, have been shown to be potent inhibitors of methane formation in ruminants (McAllister and Newbold, 2008). However, methanogen species differ in their sensitivity to these analogs (Ungerfeld et al., 2004). The qPCR analysis performed on rumen fluid showed no variation in the abundance of bacteria, protozoa, and methanogenic archaea because of BCM treatment, which agrees with the lack of variation in the concentration of total VFA. 
Table 5. Milk FA profile (g/100 g of total FA) in goats treated (BCM+) or not (BCM-) with bromochloromethane

\begin{tabular}{|c|c|c|c|c|}
\hline Item & BCM- & $\mathrm{BCM}+$ & $\mathrm{SED}^{1}$ & $P$-value \\
\hline \multicolumn{5}{|l|}{ SFA } \\
\hline $4: 0$ & 2.66 & 2.65 & 0.120 & 0.939 \\
\hline $5: 0$ & 0.02 & 0.02 & 0.002 & 0.958 \\
\hline $6: 0$ & 4.15 & 4.46 & 0.191 & 0.126 \\
\hline $7: 0$ & 0.04 & 0.04 & 0.005 & 0.714 \\
\hline $8: 0$ & 3.32 & 3.75 & 0.201 & 0.054 \\
\hline 9:0 & 0.07 & 0.08 & 0.010 & 0.726 \\
\hline 10:0 & 11.57 & 13.09 & 0.725 & 0.055 \\
\hline 11:0 & 0.11 & 0.11 & 0.017 & 0.858 \\
\hline $12: 0$ & 5.69 & 6.10 & 0.570 & 0.489 \\
\hline $14: 0$ & 11.06 & 11.56 & 0.542 & 0.375 \\
\hline $15: 0$ & 0.70 & 0.73 & 0.041 & 0.572 \\
\hline $15: 0$ iso & 0.17 & 0.17 & 0.020 & 0.862 \\
\hline 15:0 anteiso & 0.24 & 0.25 & 0.020 & 0.893 \\
\hline $16: 0$ & 27.81 & 27.58 & 1.091 & 0.833 \\
\hline $17: 0$ & 0.45 & 0.47 & 0.027 & 0.513 \\
\hline 17:0 iso & 0.25 & 0.23 & 0.011 & 0.248 \\
\hline 17:0 anteiso & 0.38 & 0.35 & 0.024 & 0.171 \\
\hline $18: 0$ & 6.41 & 6.55 & 0.822 & 0.865 \\
\hline 19:0 & 0.07 & 0.06 & 0.007 & 0.212 \\
\hline $20: 0$ & 0.14 & 0.14 & 0.017 & 0.937 \\
\hline $21: 0$ & 0.03 & 0.03 & 0.004 & 0.558 \\
\hline $22: 0$ & 0.03 & 0.03 & 0.005 & 0.906 \\
\hline $24: 0$ & 0.01 & 0.01 & 0.004 & 0.750 \\
\hline \multicolumn{5}{|l|}{ MUFA } \\
\hline cis-9 14:1 & 0.18 & 0.16 & 0.019 & 0.163 \\
\hline cis-9 16:1 & 0.73 & 0.55 & 0.088 & 0.062 \\
\hline trans-9 16:1 & 0.40 & 0.36 & 0.048 & 0.381 \\
\hline cis-9 $18: 1^{2}$ & 14.46 & 13.19 & 0.973 & 0.212 \\
\hline cis-11 18:1 & 0.33 & 0.28 & 0.039 & 0.169 \\
\hline cis-12 18:1 & 0.24 & 0.17 & 0.044 & 0.150 \\
\hline cis-13 18:1 & 0.06 & 0.04 & 0.011 & 0.088 \\
\hline cis-14 18:1 & 0.04 & 0.03 & 0.006 & 0.113 \\
\hline cis-16 18:1 & 0.05 & 0.04 & 0.007 & 0.219 \\
\hline trans-4 18:1 & 0.01 & 0.01 & 0.002 & 0.168 \\
\hline trans-5 18:1 & 0.02 & 0.01 & 0.002 & 0.074 \\
\hline trans-6-8 18:1 & 0.22 & 0.16 & 0.029 & 0.068 \\
\hline trans-9 18:1 & 0.25 & 0.18 & 0.029 & 0.023 \\
\hline trans-10 18:1 & 0.56 & 0.30 & 0.156 & 0.123 \\
\hline trans-11 18:1 & 0.73 & 0.53 & 0.147 & 0.197 \\
\hline trans-12 18:1 & 0.23 & 0.19 & 0.034 & 0.367 \\
\hline trans-15 $18: 1^{3}$ & 0.08 & 0.07 & 0.012 & 0.420 \\
\hline trans-16 18:1 & 0.18 & 0.16 & 0.024 & 0.588 \\
\hline cis-11 20:1 & 0.08 & 0.06 & 0.007 & 0.031 \\
\hline \multicolumn{5}{|l|}{ PUFA } \\
\hline cis-9,cis-12 18:2 & 2.10 & 1.91 & 0.253 & 0.469 \\
\hline cis-9,trans-12 18:2 & 0.04 & 0.03 & 0.007 & 0.050 \\
\hline trans-9,cis-12 18:2 & 0.03 & 0.03 & 0.005 & 0.139 \\
\hline trans-9,trans-12 18:2 & 0.02 & 0.01 & 0.002 & 0.060 \\
\hline trans-11,cis-15 18:2 & 0.05 & 0.02 & 0.014 & 0.139 \\
\hline cis-9,trans-11 CLA ${ }^{4}$ & 0.50 & 0.33 & 0.104 & 0.129 \\
\hline trans-11,trans-13 CLA & 0.01 & 0.02 & 0.002 & 0.804 \\
\hline Other trans-trans $\mathrm{CLA}^{5}$ & 0.03 & 0.02 & 0.003 & 0.041 \\
\hline$\Sigma$ CLA & 0.66 & 0.45 & 0.115 & 0.086 \\
\hline cis-6,cis-9,cis-12 18:3 & 0.03 & 0.02 & 0.002 & 0.016 \\
\hline cis-9,cis-12,cis-15 18:3 & 0.27 & 0.29 & 0.062 & 0.656 \\
\hline cis-11,cis-14 20:2 & 0.02 & 0.03 & 0.006 & 0.069 \\
\hline cis-8,cis-11,cis-14 20:3 & 0.03 & 0.02 & 0.003 & 0.087 \\
\hline cis-11,cis-14,cis-17 20:3 & 0.02 & 0.01 & 0.007 & 0.060 \\
\hline cis-5,cis-8, cis-11,cis-14 20:4 & 0.09 & 0.06 & 0.009 & 0.016 \\
\hline cis-5,cis-8,cis-11,cis-14,cis-17 20:5 & 0.03 & 0.03 & 0.004 & 0.586 \\
\hline
\end{tabular}

${ }^{1} \mathrm{SED}=$ standard error of the difference.

${ }^{2}$ Contains trans-13 and trans-14 18:1 as minor components.

${ }^{3}$ Coelutes with cis-10 18:1.

${ }^{4}$ Contains trans-7, cis-9 conjugated linoleic acid (CLA) and trans-8,cis-10 CLA as minor components.

${ }^{5}$ Sum of trans-7,trans-9 CLA + trans-8, trans-10 CLA + trans-9, trans-11 CLA + trans-10,trans-12 CLA. 
Goel et al. (2009) reported no changes in the concentration of total bacteria and protozoa, and a complete inhibition of methanogenic archaea as a result of adding BCM in batch cultures and continuous fermenters. The disagreement between our results and those obtained by Goel et al. (2009) concerning the effect on archaeal numbers might be explained by the duration of the trials and therefore the time that the microbial ecosystem had to adapt to the treatment. Williams et al. (2009) reported that methanogens take longer than 4 wk to adapt to dietary changes, compared with only 10 to 15 $\mathrm{d}$ for the eubacterial community. Our results support the hypothesis that, rather than the number, it is the distribution of different species that drives the synthesis of methane in the rumen (Morgavi et al., 2010). Using denaturing gradient gel electrophoresis, we have observed that BCM specifically affects the archaeal community structure, probably knocking out those with greater methanogenic activity (Abecia et al., 2011). In vivo studies carried out recently (Zhou et al., 2010) have shown that animals that emit less methane in a herd have a different archaeal community compared with those that produce more methane, regardless of the total archaeal biomass in the rumen.

\section{Milk Yield and Composition}

Goats in the BCM+ group produced significantly more milk than goats in the BCM- group, and DMI was equivalent to approximately $2.5 \%$ of $\mathrm{BW}$. The diet used in this study theoretically accommodated maintenance requirements plus the production of $1 \mathrm{~kg}$ of milk/d (NRC, 2007). This value is, in fact, close to that observed for BCM- goats. To our knowledge, this is the first report on the use of BCM, or other halogenated analogs, in lactating ruminants.

The $36 \%$ increase in milk yield in BCM+ goats involves an energy cost of $4.48 \mathrm{MJ} / \mathrm{d}$ in milk production compared with $3.39 \mathrm{MJ} / \mathrm{d}$ in control goats. The energy balance that results from deducting methane losses to energy intake leaves an extra $1.09 \mathrm{MJ} / \mathrm{d}$ available to the animal. In addition, and assuming a similar rumen content volume in both experimental groups (around $11 \%$ of BW, D. R. Yáñez-Ruiz, unpublished data) and equal absorption efficiency of $\mathrm{VFA}, \mathrm{BCM}+$ goats absorbed $91 \%$ more propionate than BCM- animals (55.6 vs. $29.1 \mathrm{mmol} / \mathrm{d}$, respectively). Such an increase in propionate production would lead to an increase in glucose synthesis and hence in milk lactose, assuming a $70 \%$ efficiency in the conversion of propionate to glucose and a $40 \%$ conversion of glucose to lactose (Newbold et al., 2005). Thus, the combination of lower methane losses and the increase in glucose synthesis from propionate supply explains the increase in milk production efficiency observed here.

The imbalance in the distribution of electrons in methane explains the higher molar proportion of propionate in rumen fluid from treated goats. An increase in propionate production could have led to a higher synthesis of glucose in the liver, which may result in an increase in the synthesis of lactose in the mammary gland (Newbold et al., 2005). Because milk is isotonic with respect to blood, and lactose contributes some $60 \%$ of milk osmolarity, an increase in lactose flow to the mammary gland would result in greater milk yield (Tamminga et al., 2007). Unfortunately, our results were not directly comparable with available reports in dairy cows because of the important differences in the strategies for methane mitigation tested. The addition of lipids to the diet of dairy cows has been shown to reduce methane emissions, but the levels of supplementation normally used can be associated with decreased DMI (Beauchemin et al., 2008). The reduction in methane emissions achieved by adding lipids is not necessarily accompanied by an increase in milk yield, even if they are combined with other type of additives such as organic acids (van Zijderveld et al., 2011).

The genetic potential for milk yield from the breed of dairy goats used in this study would be expected to be higher than the value observed in the control. This is due to the relatively low amount of feed offered to animals to facilitate intake measurements during methane measurements in the chambers. It is reasonable to anticipate that the increase in lactose yield, and subsequently milk yield, would be accompanied by comparable increases in fat or protein yield and, probably, greater losses in BW during lactation. However, this was not the case, and neither was the dilution effect in response to higher milk yield (i.e., the reduction in the concentration of fat and protein) significant. Treated goats varied greatly in how they responded to BCM treatment; we hypothesize that this depends, among other reasons, on the initial methanogen populations they harbored prior to the start of the experiment, as observed by denaturing gradient gel electrophoresis in a previous work (Abecia et al., 2011). This variability in the response resulted in a high inter-animal variation in this study for milk variables, contributing to the lack of significant changes.

The benefit of BCM administration for improving milk production efficiency did not have a major effect on milk FA profile, and the most evident changes observed were the trend toward slightly lower MUFA concentration and a marginal increase in SFA. However, because this latter effect was due to higher proportions of some metabolically valuable short-chain FA (Park 
et al., 2007; Sanz Sampelayo et al., 2007), it could be suggested that these changes in milk FA profile had no detrimental effect on the nutritive value of goat milk.

In the bovine, a few studies have attempted to relate changes in rumen methane production with milk FA composition (e.g., Vlaeminck and Fievez, 2005; Chilliard et al., 2009; van Zijderveld et al., 2011). Dietary treatments that have been successful in inhibiting methanogenesis are usually associated with shifts in odd- and branched-chain FA (potential microbial markers) in milk. However, these results can be variable and decreases in rumen methanogenesis have been related to an increase (Vlaeminck and Fievez, 2005), no variation (Chilliard et al., 2009), or a decrease (van Zijderveld et al., 2011) in the concentration of 15:0 iso in milk. The validity of these results is often limited to the treatments under investigation (Chilliard et al., 2009). In the present study, no variations in milk oddand branched-chain FA were observed. Furthermore, the lack of major changes in the concentration of rumen biohydrogenation-derived FA did not appear to be consistent with an apparent shift in microbial populations. Therefore, the reduction in the proportion of some long-chain FA in milk might be simply explained, at least partially, by a possible dilution effect due to the increase in those FA originating from de novo synthesis. This experiment was conducted in early lactation, a time when ruminants mobilize some body fat to support milk production; therefore, the lack of a major effect on FA profile in milk would need to be further studied in mid-lactation animals receiving diets with higher levels of fat.

\section{CONCLUSIONS}

This study, using complexed bromochloromethane fed to lactating dairy goats, further confirms the potent methane inhibition potential of this halogenated compound. The sharp reduction of methane emissions was associated with an increase in milk yield, probably due to favorable propionic rumen fermentation, but fat, protein, casein, and lactose concentrations in milk were unaffected by treatment. Bromochloromethane did not affect either the abundance of rumen bacteria and protozoa or that of total methanogenic archaea. Moreover, in this study, a minor change in milk fatty acid profile was observed, which suggests that the important decrease in methane production was not related to alterations in ruminal biohydrogenation pathways. Compounds that influence terminal biochemical pathways for $\mathrm{CH}_{4}$ production deserve further development for future application in the dairy goat sector.

\section{ACKNOWLEDGMENTS}

This research has been funded by the European Commission (Marie Curie Reintegration Grant 224816METANORUMEN) and the Spanish Science and Innovation Ministry (AGL2008-04707-C02-01). We gratefully acknowledge I. Jiménez (EEZ-CSIC Granada, Spain) for her technical assistance and Puleva Food S.L. (Granada, Spain) for analysis of milk components. L. Abecia acknowledges receipt of a research contract from the Spanish National Research Council (CSIC, JAE-doc Programme).

\section{REFERENCES}

Abecia, L., A. I. Martín-García, G. Martínez, N. W. Tomkins, E. Molina-Alcaide, C. J. Newbold, and D. R. Yáñez-Ruiz. 2011. Manipulation of the rumen microbial ecosystem to reduce methane emissions in ruminants through the intervention at early life stage of pre-ruminants and their mothers. Adv. Anim. Biosciences 2:271. Proc. 8th Int. Symp. Nutrition of Herbivores, Aberystwyth, UK. Cambridge University Press, Cambridge, UK.

AOAC. 2005. Official Methods of Analysis. 18th ed. Association of Official Analytical Chemists International, Gaithersburg, MD.

Beauchemin, K. A., M. Kreuzer, F. O'Mara, and T. A. McAllister. 2008. Nutritional management for enteric methane abatement: A review. Aust. J. Exp. Agric. 48:21-27.

Bernard, L., K. J. Shingfield, J. Rouel, A. Ferlay, and Y. Chilliard. 2009. Effect of plant oils in the diet on performance and milk fatty acid composition in goats fed diets based on grass hay or maize silage. Br. J. Nutr. 101:213-224.

Blaxter, K. L., and J. L. Clapperton. 1965. Prediction of the amount of methane produced by ruminants. Br. J. Nutr. 19:511-522.

Chilliard, Y., C. Martin, J. Rouel, and M. Doreau. 2009. Milk fatty acids in dairy cows fed whole crude linseed, extruded linseed, or linseed oil, and their relationship with methane output. J. Dairy Sci. 92:5199-5211.

Choi, N. J., S. Y. Lee, H. G. Sung, S. C. Lee, and J. K. Ha. 2004. Effects of halogenated compounds, organic acids and unsaturated fatty acids on in vitro methane production and fermentation characteristics. Asian-australas. J. Anim. Sci. 17:1255-1259.

Denman, S. E., N. W. Tomkins, and C. S. McSweeney. 2007. Quantification and diversity analysis of ruminal methanogenic populations in response to the antimethanogenic compound bromochloromethane. FEMS Microbiol. Ecol. 62:313-322.

Eugène, M., D. Massé, J. Chiquette, and C. Benchaar. 2008. Short communication: Meta-analysis on the effects of lipid supplementation on methane production in lactating dairy cows. Can. J. Anim. Sci. 88:331-334.

Goel, G., H. P. S. Makkar, and K. Becker. 2009. Inhibition of methanogens by bromochloromethane: Effects on microbial communities and rumen fermentation using batch and continuous fermentations. Br. J. Nutr. 101:1484-1492.

Hart, K. J., D. R. Yáñez-Ruiz, S. M. Duval, N. R. McEwan, and C. J. Newbold. 2008. Plant extracts to manipulate rumen fermentation. Anim. Feed Sci. Technol. 147:8-35.

Isac, M. D., M. A. García, J. F. Aguilera, and E. Molina-Alcaide. 1994. A comparative study of nutrient digestibility, kinetics of digestion and passage and rumen fermentation pattern in goats and sheep offered medium quality forages at the maintenance level of feeding. Arch. Tierernahr. 46:37-50.

ISO. 1999. Whole milk-Determination of milk fat, protein and lactose content: Guidance of operation of mid-infrared instruments. ISO Standard No. 9622. International Organization for Standardization, Geneva, Switzerland. 
Janssen, P. H. 2010. Influence of hydrogen on rumen methane formation and fermentation balances through microbial growth kinetics and fermentation thermodynamics. Anim. Feed Sci. Technol. 160:1-22.

Johnson, K. A., and D. E. Johnson. 1995. Methane emissions from cattle. J. Anim. Sci. 73:2483-2492.

Kramer, J. K. G., M. Hernandez, C. Cruz-Hernandez, J. Kraft, and M. E. R. Dugan. 2008. Combining results of two GC separations partly achieves determination of all cis and trans 16:1, 18:1, 18:2 and 18:3 except CLA isomers of milk fat as demonstrated using Ag-ion SPE fractionation. Lipids 43:259-273.

Luna, P., A. Bach, M. Juárez, and M. A. de la Fuente. 2008. Effect of a diet enriched in whole linseed and sunflower oil on goat milk fatty acid composition and conjugated linoleic acid isomer profile. J. Dairy Sci. 91:20-28.

Maeda, H., C. Fujimoto, Y. Haruki, T. Maeda, S. Kokeguchi, M. Petelin, H. Arai, I. Tanimoto, F. Nishimura, and S. Takashiba. 2003. Quantitative real-time PCR using TaqMan and SYBR Green for Actinobacillus actinomycetemcomitans, Porphyromonas gingivalis, Prevotella intermedia, tetQ gene and total bacteria. FEMS Immunol. Med. Microbiol. 39:81-86.

May, C., A. Payne, P. Stewart, and J. Edgar, inventors. 1995. A delivery system for agents. CSIRO, assignee. International Patent Application No. PCT/AU95/700733.

McAllister, T. A., and C. J. Newbold. 2008. Redirecting rumen fermentation to reduce methanogenesis. Aust. J. Exp. Agric. 48:7-13.

Morgavi, D. P., E. Forano, C. Martin, and C. J. Newbold. 2010. Microbial ecosystem and methanogenesis in ruminants. Animal 4:1024-1036.

Newbold, C. J., S. Lopez, N. Nelson, J. O. Ouda, R. J. Wallace, and A. R. Moss. 2005. Propionate precursors and other metabolic intermediates as possible alternative electron acceptors to methanogenesis in ruminal fermentation in vitro. Br. J. Nutr. 94:27-35.

NRC. 2007. Nutrient Requirements of Small Ruminants: Sheep, Goats, Cervids, and New World Camelids. National Research Council, Washington, DC.

Park, Y. W., M. Juárez, M. Ramos, and G. F. W. Haenlein. 2007. Physico-chemical characteristics of goat and sheep milk. Small Rumin. Res. 68:88-113.

Parodi, P. W. 2009. Has the association between saturated fatty acids, serum cholesterol and coronary heart disease been over emphasized? Int. Dairy J. 19:345-361.

Prieto, C., J. F. Aguilera, L. Lara, and J. Fonollá. 1990. Protein and energy requirements for maintenance of indigenous Granadina goats. Br. J. Nutr. 63:155-163.

Rodríguez-Alcalá, L. M., F. Harte, and J. Fontecha. 2009. Fatty acid profile and CLA isomers content of cow, ewe and goat milks processed by high pressure homogenization. Innov. Food Sci. Emerg. Technol. 10:32-36.
Sanz Sampelayo, M. R., Y. Chilliard, P. Schmidely, and J. Boza. 2007. Influence of type of diet on the fat constituents of goat and sheep milk. Small Rumin. Res. 68:42-63.

Shingfield, K. J., S. Ahvenjärvi, V. Toivonen, A. Äröla, K. V. V. Nurmela, P. Huhtanen, and J. M. Griinari. 2003. Effect of dietary fish oil on biohydrogenation of fatty acids and milk fatty acid content in cows. Anim. Sci. 77:165-179.

Steinfeld, H., P. Gerber, T. Wassenaar, V. Castel, M. Rosales, and C. de Haan. 2006. Livestock's Long Shadow: Environmental Issues and Options. Food and Agriculture Organization of the United Nations, Rome, Italy.

Sylvester, J. T., S. K. Karnati, Z. Yu, M. Morrison, and J. L. Firkins. 2004. Development of an assay to quantify rumen ciliate protozoal biomass in cows using real-time PCR. J. Nutr. 134:3378-3384.

Tamminga, S., A. Bannink, J. Dijkstra, and R. Zom. 2007. Feeding strategies to reduce methane loss in cattle. Report 34. Animal Sciences Group, Wageningen UR, Lelystad, the Netherlands.

Tomkins, N. W., S. M. Colegate, and R. A. Hunter. 2009. A bromochloromethane formulation reduces enteric methanogenesis in cattle fed grain-based diets. Anim. Prod. Sci. 49:1053-1058.

Ungerfeld, E. M., S. R. Rust, D. R. Boone, and Y. Liu. 2004. Effects of several inhibitors on pure cultures of ruminal methanogens. J. Appl. Microbiol. 97:520-526.

Van Soest, P. J., J. B. Robertson, and B. A. Lewis. 1991. Methods for dietary fiber, neutral detergent fiber and non-starch polysaccharides in relation to animal nutrition. J. Dairy Sci. 74:3583-3597.

van Zijderveld, S. M., B. Fonken, J. Dijkstra, W. J. J. Gerrits, H. B Perdok, W. Fokkink, and J. R. Newbold. 2011. Effects of a combination of feed additives on methane production, diet digestibility, and animal performance in lactating dairy cows. J. Dairy Sci. 94:1445-1454.

Vlaeminck, B., and V. Fievez. 2005. Milk odd and branched chain fatty acids to predict ruminal methanogenesis in dairy cows. Commun. Agric. Appl. Biol. Sci. 70:43-47.

Williams, Y. J., S. Popovski, S. M. Rea, L. C. Skillman, A. F. Toovey, K. S. Northwood, and A. D. G. Wright. 2009. A vaccine against rumen methanogens can alter the composition of archaeal populations. Appl. Environ. Microbiol. 75:1860-1866.

Wood, J. M., F. S. Kennedy, and R. S. Wolfe. 1968. The reaction of multi-halogenated hydrocarbons with free and bound reduced vitamin $\mathrm{B}_{12}$. Biochemistry 7:1707-1713.

Zhou, M., E. Hernandez-Sanabria, and L. L. Guan. 2010. Characterization of variation in rumen methanogenic communities under different dietary and host feed efficiency conditions, as determined by PCR-denaturing gradient gel electrophoresis analysis. Appl. Environ. Microbiol. 76:3776-3786. 